\title{
Revista

\section{Respeitem meus cabelos, brancos: música, política e identidade negra}

\section{Have some respect for my hair, whites: music, politics and black identity}

FELIPE DA COSTA TROTTA

Professor do Programa de Pós-Graduação em Comunicação da Universidade Federal Fluminense (UFF). <trotta.felipe@gmail.com>

KYWZA J. F. P. DOS SANTOS

Doutoranda do Programa de Pós-Graduação em Comunicação da UFPE. <kywzafideles@gmail.com>

\section{RESUMO}

A música popular é um artefato midiático através do qual são negociados socialmente pensamentos, valores, ações e estratégias de identidade individual e coletiva. Neste artigo, analisaremos as nuances discursivas que integram a canção Respeitem meus cabelos, brancos, de Chico César. Parte-se da hipótese de que por trás de um discurso militante e acusatório revelam-se diversas ambiguidades discursivas que integram a posição do autor sobre identidade negra. Os debates atuais sobre racismo acionam um posicionamento dicotômico (brancos $\mathrm{x}$ negros), presente na letra, mas relativizado pela ironia do uso não ortodoxo do reggae, pela ambiguidade da capa do $C D$, pela indefinição tonal e pelo criativo uso da vírgula, que condensa toda uma gama de deslocamentos interpretativos, contribuindo densa e criticamente para o pensamento atual sobre negritude no Brasil.

Palavras-chave: Música popular; Identidade negra; Chico César.

\section{ABSTRACT}

Popular music is a media artifact through which thoughts, values, actions and collective and individual strategies of identity can be socially negotiated. In this article, we'll analyze the discursive nuances in the song Respeitem meus cabelos, brancos (Have some respect for my hair, whites), by Chico César. We start of from the assumption that behind a militant and accusatory discourse, ambiguities are showed in the author's stand on black identity. Current debates on racism trigger a dichotomous position (blacks vs. whites), in the lyrics, second guessed by the irony in the unorthodox usage of reggae, by the ambiguity of the record cover image, by the undefined tone and the creative use of the comma, that condenses a range of interpretational misplaces, contributing largely and critically for the current thought on blackness in Brazil.

Keywords: Popular music; Black identity; Chico César. 


\section{Quando o preto fala...}

S artefatos culturais midiáticos reverberam pela sociedade visões de mundo, sentimentos e estratégias de pertencimento que são negociados a partir de sua apropriação. Nesse sentido, a "cultura da mídia" é um campo de debates, disputas, negociações e, por vezes, consensos coletivos (Kellner, 2001, p. 10). Os produtos veiculados em larga escala são, portanto, políticos; e, eventualmente, alguns desses produtos mexem de forma bastante direta em temas densos e espinhosos, com variados graus de alcance e ressonância.

Para este artigo, isolamos a canção Respeitem meus cabelos, brancos ${ }^{1}$, lançada em 2002, pelo cantor e compositor paraibano Chico César. A simbiose entre as representações da identidade negra e a música popular são apontadas por diversos autores, que sublinham a importância deste artefato cultural como eixo de negociação da luta dos negros contra o racismo em todo o mundo. Stuart Hall situa a música, ao lado da corporalidade e do "estilo", um dos três elementos significativos que constituem o "repertório negro" (2003, p. 342). Para Paul Gilroy, em seu clássico O Atlântico Negro,

examinar o lugar da música no mundo do Atlântico negro significa observar a autocompreensão articulada pelos músicos que a têm produzido, o uso simbólico que lhe é dado por outros artistas e escritores negros e as relações sociais que têm produzido e reproduzido a cultura expressiva única, na qual a música constitui um elemento central e mesmo fundamental.

(2001, p. 161). 
Essa perspectiva ecoa a noção - cara à etnomusicologia - de que a música é "um sistema de pensamento humano e parte da infraestrutura da vida humana", sendo a experiência musical uma "ação social que pode ter importantes consequências em outras formas de ação social" (Blacking, 1995, p. 223). No Brasil, diversos autores (Sodré, 1998; Sandroni, 2001; Coutinho, 2001) buscam estabelecer nexos estreitos entre a construção da identidade negra e o samba, sublinhando seu caráter político. Além do prestigiado gênero, é possível afirmar que, do maracatu ao hip hop, do jongo ao tambor de crioula, quase todas as práticas musicais associadas à identidade nacional ou regional apresentam de alguma forma conexões com debates sobre negritude, escravidão e subalternização. A própria identidade nacional está atravessada pela conflituosa negociação do papel da população negra na sociedade, balizada pela escravidão e pelo racismo.

Chegamos ao século XXI com um intenso debate sobre cotas e discriminação - que se relaciona com um debate internacional sobre alteridade - movido num terreno de forte densidade conceitual e emotiva. O tempero da temática é atravessado pela tensão entre o "ideal da democracia racial", forjada a partir das teorias da mestiçagem dos anos 1930, e a constatação de que "um racismo brutal vigora entre nós" (Schwarcz, 2007, p. 21). Apesar de não ser exatamente uma novidade (o livro de Florestan Fernandes que critica o mito da democracia racial foi lançado em 1966!), a denúncia do racismo passou a ser algo frequente em nosso cotidiano. Numa resposta a Caetano Veloso que, em 2007, ao analisar a canção Feitiço da Vila, de Noel Rosa, "acusou" seu autor de racismo, o etnomusicólogo Carlos Sandroni mapeia esse momento atual: 
As discussões sobre racismo estão acesas no Brasil, em grande parte por causa da Lei de Cotas. Isso me parece muito bom, mas estão também gerando um efeito colateral que, este, me parece nocivo. A total banalização da acusação de racismo! [...] Neste quadro, a acusação de racismo corre o risco de ficar cada vez mais fraca. Racismo é crime, mas se uns e outros são racistas, e até Noel Rosa é racista (sem falar dos outros sambistas que falaram mal do feitiço), pode se difundir o sentimento de que o tal racismo não deve ser coisa tão grave assim. (Dizendo isto arrisco-me, é claro, a ser chamado de racista). É certo que, como apenas 120 anos nos separam do regime escravista, ainda existe na sociedade brasileira um racismo estrutural, do qual, em alguma medida, creio que todos podemos ser 'acusados'.

(Obra em Aberto, 2008)²

Respeitem meus cabelos, brancos pode ser incluída neste movimento de denúncia, operando numa lógica de certa forma acusatória que sublinha o preconceito e exige mudanças de atitudes. Por outro lado, esse tipo de postura tem sido problematizada por seu viés "essencializante", pois opera a partir de uma oposição entre "preto" e "branco" que acaba acentuando a vetor "raça" como agente de valor.

O momento essencializante é fraco porque naturaliza e deshistoriciza a diferença, confunde o que é histórico e cultural com o que é natural, biológico e genético. No momento em que o significante 'negro' é arrancado de seu encaixe histórico, cultural e político, e é alojado em uma categoria racial biologicamente construída, valorizamos, pela inversão, a própria base do racismo que estamos tentando desconstruir.

(Hall, 2003, p. 326-327) 
Contudo, a complexidade dos discursos musicais midiatizados se sobrepõe à essencialização do pensamento, provocando deslocamentos instigantes que, ao contrário, reposicionam o debate e negociam modelos de construção de identidade e pertencimento, entre o mito pacificador da democracia racial e a estratégia belicista de denúncia do racismo. A análise da canção pode apontar diversos procedimentos musicais que condensam múltiplos eixos discursivos sobre identidade negra, mantendo-se numa posição antirracista firme e inequívoca, mas elaborada a partir de uma conciliação um tanto ambígua entre orgulho negro, denúncia, manifesto, e ironia. Numa lógica um tanto paradoxal, se o humor é uma característica da sociedade brasileira (Sovik, 2009, p. 80), a ambiguidade irônica é um recurso para abordar temáticas densas e conflituosas com seriedade. Além da dicotomia branco x preto, é possível identificar na música diversas ambiguidades críticas relacionadas ao cabelo, à capa do $\mathrm{CD}$, ao uso da vírgula, da tonalidade e do gênero musical.

\section{Reggae: identidade negra internacional-popular}

Chico César é um artista cuja obra pode ser classificada sem muita dificuldade no termo MPB, caracterizada pelo uso de harmonias complexas, poesia sofisticada e apuro de arranjos e instrumentações. Seu repertório não se restringe a nenhum gênero musical específico, variando ao sabor de sua inspiração entre a balada, o coco, o forró, o frevo, o reggae e vários outros ritmos e levadas. No entanto, em termos de construção identitária, o compositor reafirma em sua música duas marcas de modo recorrente: a sua negritude e sua nordestinidade. Sonoramente, uma das construções rítmicas mais contundentes dessa afirmação se materializa na utilização frequente do reggae e do xote. Os dois gêneros formam uma espécie de terreno musical e simbólico a partir do qual o autor tece misturas e 
experimentações instrumentais, construindo uma apropriação não ortodoxa das "regras de gênero" (Fabbri, 1982) que caracterizam tornam os gêneros musicais reconhecíveis.

Respeitem meus cabelos, brancos é um reggae. Reconhecer um gênero implica em acessar "modos de mediação entre as estratégias produtivas e o sistema de recepção, entre os modelos e os usos que os receptores fazem desses modelos através das estratégias de leitura dos produtos midiáticos" (Janotti Jr., 2006, p. 6). A recorrência na utilização de um gênero por um determinado cantor ou compositor intensifica essa mediação e os significantes culturais relacionados ao gênero. Ao adotar frequentemente o reggae como forma de expressão, Chico César elabora um discurso político-musical ancorado na mensagem genérica do gênero como ação contra o preconceito racial. Porém, ao contrário de uma utilização ortodoxa do reggae como "canção de protesto", séria e excludente, o compositor torce palavras e sonoridades buscando significados mais abertos. Um de seus maiores sucessos, a canção Mama África, lançada em 1996, é um reggae. A ironia de uma mítica África Mãe convertida em mãe solteira e funcionária das Casas Bahia exprime uma rede de significados multidirecional, que concilia denúncia, resistência, crítica, dança, alegria e bom humor.

Por outro lado, a mensagem política do reggae se desenvolve a partir do que Peter Fry chama de "estilo binário" ou "bipolar" de construção da identidade negra. Ao analisar uma reportagem sobre um caso de racismo contra a filha do governador do Espírito Santo publicada na revista Veja (07.06.1993), Fry discute os modos de classificação através da aparência presentes no texto e complementa-os com breve pesquisa feita com seus vizinhos. 
O narrador [da reportagem] e Waldicéia [esposa do governador] distribuem as personagens em apenas duas categorias: 'negros' $e$ 'brancos'. As demais personagens e os meus vizinhos utilizam categorias muito comuns na vida cotidiana brasileira como 'moreno', 'morena clara', 'mulato(a)', 'mulato fechado', 'pardo', 'criolo', 'neguinho', 'loira' e 'preto(a)' para colocar as personagens numa gama de categorias bem mais ampla. Chamo a primeira maneira de classificar de 'modo binário', e a segunda de 'modo múltiplo'. [...] Há também um terceiro modo de classificação, uma espécie de redução do modo múltiplo, ou ampliação do modo bipolar, que consiste em três categorias: 'negro', 'branco' e 'mulato'. Este é também o modo oficial do censo brasileiro, que pede às pessoas que se classifiquem como 'pretas', 'brancas' ou 'pardas' (quando não 'amarelas' ou 'outras'). Nota-se um deslizamento das categorias 'negro' e 'mulato' para 'preto' e 'pardo'.

(Fry, 1996, p. 131)

O modelo bipolar teria a desvantagem, segundo o autor, de essencializar a "raça" e anular possíveis negociações classificatórias relacionadas à "aparência". Para Fry, esse modo de classificação é característico da sociedade norte-americana e sua aplicação no Brasil é insatisfatória, pois neutraliza certas complexidades e peculiaridades do racismo brasileiro (Fry, 1996, p. 133). Porém, reconhece que o modelo binário oferece possibilidades de inversão valorativa, a partir da qual elementos associados à aparência negra, historicamente depreciados podem se reposicionar positivamente enquanto signos de orgulho e identificação. 
Adicionalmente, a própria globalização de símbolos de negritude e sua ação política a partir da década de 1960 têm enfatizado a distinção bipolar como estratégia de luta contra o racismo. No campo da música, o jazz, o reggae e o samba são alguns elementos de valorização da "cultura negra". O reggae permite a Chico César nesta e em várias outras canções (como Mand'ela, Filá, Dá Licença $M^{\prime}$, Perto demais de Deus, Nas fronteiras do mundo, entre outras) uma apropriação moderna e pop da identidade negra, tencionando os modelos convencionais de identificação com batuques, danças e tambores.

Surgido na Jamaica no final dos anos 1960 a partir de gradativas alterações no ska e no rock steady, o reggae fixa-se no imaginário internacional a partir de meados da década de 1970, sobretudo através da obra de Jimmy Cliff, Bob Marley e seu grupo, The Wailers (Rommen, 2006). A internacionalização do reggae espalha por vários cantos do mundo uma mensagem de ação política de valorização da identidade negra, moldando um universo comum de referências atravessadas pelas ideias de luta contra a dominação e exploração. Beneficiando-se da utilização de diversos símbolos reconhecidos internacionalmente (a guitarra, as drogas, o inglês), o reggae jamaicano foi facilmente assimilado tanto nos países centrais anglófonos (Inglaterra e Estados Unidos) quanto nas periferias mundiais que reconhecem tais símbolos como pertencentes a um fluxo de comunicação transnacional (ver Ortiz 2008).

No Brasil, a chegada do reggae jamaicano via Estados Unidos ocorre em meados da década de 1970 e encontra reverberação significativa. No Maranhão, estado com expressivo percentual de população negra, o reggae é promovido por circuitos alternativos através de "sistemas de som" improvisados - as "radiolas" -, percorrendo caminho análogo ao trilhado na própria Jamaica. O reggae de São Luis é tematizado por Chico César (em parceria com Zeca Baleiro) na canção Pedra de responsa, que não é um reggae, mas na qual desenvolve uma apologia da "ilha" de São Luís e de seus 
elementos mais característicos: o arroz de cuxá, o boi bumbá e o reggae (este acionado pela letra com menções à música, a "pedra de responsa" 3 e à maconha, o "cigarrinho"). Novamente aqui o autor evoca consonâncias com as identificações relacionadas ao Nordeste e sua identidade negra.

No campo prestigiado da MPB, o cantor e compositor Gilberto Gil foi possivelmente o primeiro a manifestar-se de modo eficaz no estilo reggae, em seu emblemático disco Realce, de 1977, no qual gravou uma versão da célebre canção No woman no cry, de Bob Marley. A gravação colaborou para sedimentar o sucesso do cantor jamaicano em espaços mercadológicos não necessariamente identificados com o reggae e o rastafarianismo, ampliando a gama de significações que atravessam o gênero em sua circulação transnacional. As mensagens genéricas de resistência, o campo comum da luta contra o preconceito e a discriminação racial desprendem-se das narrativas salvacionistas da ideologia rasta e moldam-se a um fluxo internacional de ideias e pensamentos sobre as várias formas de dominação e injustiças sociais. Tal movimento permite a utilização do reggae como uma música-conceito, mais do que uma integração religiosa, construindo um terreno fértil para sua disseminação em várias searas da MPB.

Neste mesmo álbum, Gil iria gravar o reggae pop Sarará miolo que questionava altivamente o preconceito. Na letra da canção, a personagem Sara será "curada" da doença de negar sua negritude. Através de um criativo jogo de palavras, o cantor manifesta seu desejo pela chegada do dia em que Sara sarará e irá aceitar seu "cabelo duro" sarará. Para José Jorge de Carvalho, a eficácia desta canção tem relação direta com o jogo de palavras e com o seu humor, navegando em uma estrutura de pensamento que é capaz de agregar numa mesma pessoa as duas categorias no estilo de classificação que Fry batiza de "bipolar": branco e negro (Carvalho, 1993, p. 17). Mas é possível pensar na força expressiva dessa canção acionando também o pertencimento distanciado ao 
universo contestatório do reggae e, talvez ainda mais relevante, à negociação de uma das mais poderosas metonímias que acompanham o preconceito racial no Brasil e além dele: o cabelo.

\section{Cabelo vem da África...}

Quando falamos de identidade negra, acionamos um amplo conjunto de símbolos, identificações, ideais, preconceitos e uma longa história de segregação social baseada na ideologia da raça. Parte significativa desse corpo simbólico se manifesta visualmente nas formas como as pessoas são vistas, em sua "aparência".

A construção da identidade negra está associada a usos específicos do corpo (negro), e isso a distingue da maioria das outras identidades étnicas. Por um lado, a aparência 'negra' e a exibição de gestualidade 'negra' têm sido associados a certos comportamentos, empregos e posições sociais. Por outro lado, a aparência física, o porte e os gestos também têm sido o meio pelo qual os negros, como população racializada, reconhecem a si mesmos e, na tentativa de reverter o estigma associado à negritude, tentam adquirir status e recuperar dignidade.

(Sansone, 2007, p. 24).

O cabelo, portanto, torna-se um elemento de grande relevância por sua característica de ser manipulável. Se, em determinados momentos, a manipulação tem como objetivo camuflar a identificação negra, em outros ela é a afirmação dessa reversão de status. Em estudo em salões de beleza étnica em Belo Horizonte, Nilma Lino Gomes 
identificou grande tensão na "lida" com o cabelo, fortemente associada à auto-estima e à possibilidade de negociar as classificações relacionadas à aparência. A maioria dos frequentadores dos salões busca camuflar o pertencimento étnico/racial, investindo tempo e dinheiro nessa "lida" (Gomes, 2006, p. 27-28). A própria autora observa que sua mudança de penteados alterou a forma como sua aparência é reconhecida publicamente, variando de "negra" a "mulata" ou mesmo "morena". Ao mesmo tempo, há uma parcela minoritária dos clientes que procura os salões como forma de manipular o cabelo sem esconder sua natureza crespa, numa identificação visual e comportamental associada a atitudes de ações de reação, resistência e denúncia contra o preconceito (Gomes, 2006, p. 128).

Na música brasileira, o cabelo é uma metonímia utilizada em diversas canções para exprimir referências quase sempre preconceituosas à negritude. Desde o início do século XX, a canção popular parece continuamente atestar que o "cabelo não nega" a "cor", servindo de temática para a elaboração de um tipo peculiar de racismo arraigado na classificação étnica estereotipada e segregante, mas levemente neutralizado através do desejo sexual: a "cor não pega", por isso o amor da mulata é desejado.

Na década de 1940, a famosa Nega do cabelo duro (David Nasser e Rubens Soares) questionava sobre um pente capaz de "lidar" com o cabelo crespo, ainda atravessado por um preconceito agudo e feroz associado a um corpo que "serpenteia". Quase cinquenta anos depois, a mesma personagem será retomada por uma canção carnavalesca soteropolitana, que, quando passa, o negão começa a gritar: "pega ela aí pra passar batom na boca e na bochecha" 4 . Comumente, o preconceito racial aparece associado também a uma assimetria de poder entre gêneros, onde a mulher negra (ou a mulata) é objeto de desejo masculino e tratada como ser racializado, sexualizado e disponível para servir. O estigma da mulher-objeto se intensifica sobremaneira quando associado à identidade negra numa herança tão óbvia da relação patriarcal 
escravocrata que é desnecessário alongar-se nessa conexão. Mesmo porque, na canção Respeitem meus cabelos, brancos, a dimensão erótica dos estereótipos racistas e misóginos não está presente.

Por outro lado, o movimento Black Power acionou nas décadas de 1960/70 uma redefinição dos signos de beleza, no qual os penteados "afro" ("naturais") se tornariam uma forma de construção da autoestima, amor próprio e autoconhecimento. Na já citada Sara sarará (1978), Gilberto Gil valoriza o cabelo crespo, afirmando que "cabelo duro é preciso", numa clara alusão à ideia de "orgulho negro". Para Shirley Tate, nos corpos e cabelos "afro" está inscrita uma estética antirracista, diaspórica atlântica e negra (Tate, 2009, p. 39). De acordo com essa política, “os únicos cabelos negros autênticos seriam os dreadlocks, afro, canerow, tranças, twists e chiney bumps sem adição de nenhum cabelo comercial disponível" (Tate, 2009, p. 42). Recentemente, uma canção de Seu Jorge e Max de Castro intitulada Nego do cabelo bom (2002) segue essa mesma orientação política de valorização do cabelo "natural" e afirma que o "cabelo é bom" e pedindo no refrão para que ele não seja alisado.

Mas, aqui é importante uma ressalva. No campo da música popular a presença e valorização de atores sociais negros são maiores e a própria experiência da identidade negra pode ser vivida com mais tranquilidade do que em outros campos profissionais (Sovik, 2009, p. 157). No cotidiano das ruas, batidas policiais, entrevistas de emprego e entradas de restaurantes, a negociação de valorização da identidade negra é mais difícil. Nilma Gomes observa nos salões de beleza um movimento duplo de aceitação e rejeição do ser negro, manifesto numa tensão entre as opções de uso de cabelos "relaxados ou alongados (caros e de bom rendimento simbólico)" versus o cabelo "de textura crespa natural", com franca preferência pelas opções do alisamento ou relaxamento através da justificativa da "moda" (Gomes, 2006, p. 172). 
Ampliando um pouco mais o horizonte, vale destacar que a hierarquização de indivíduos pela aparência, na qual o cabelo assume papel decisivo, não se restringe à identificação étnica, apesar de estar indelevelmente atravessada por ela. Como aponta Kobena Mercer, "as formas através das quais nós moldamos nosso cabelo podem ser vistas tanto como expressões individuais do self quanto como corporificações das normas, das convenções e das expectativas da sociedade" (Mercer, 1987, p. 34). Um exemplo musical interessante é a canção Cabelo (1989), de Jorge Benjor e Arnaldo Antunes, que discute ironicamente o cabelo a partir dos usos e das imagens sociais que os penteados afloram: aparado, escovado, descolorido, descabelado, tingido, molhado. E arremata: "quem disse que cabelo não gosta de pente?"

Outra dimensão da metáfora capilar explorada com frequência pelos compositores é a questão geracional. Em 1948, o samba-canção Cabelos brancos de Herivelto Martins e Marino Pinto é emblemático no uso da metáfora do cabelo relacionado à idade e à desilusão amorosa. A canção integra o folclórico embate da separação do compositor Herivelto Martins e da cantora Dalva de Oliveira, amplamente explorada pelos jornais e pelas gravadoras da época. Logo no início da letra, o autor pede a seus interlocutores que "não falem dessa mulher". Afirma que sem ela vive "aos trancos e barrancos" e, ao final, pede que "respeitem ao menos" os seus "cabelos brancos". Impregnada pela forte carga dramática do samba-canção e da densidade pública da dissolução do famoso casal, a música, gravada pelo grupo Quatro Ases e um Coringa, teve grande repercussão e converteu-se em um clássico da música brasileira.

No início do século XXI, após toda essa saturação de metonímias capilares, o disco de Chico César exige respeito. E toma de empréstimo precisamente o clássico de Herivelto e Marino, convertendo sua explícita conotação geracional em uma franca posição antirracista. A seriedade de seu verso-título é reforçada pela utilização do reggae, ainda que de forma não ortodoxa, mas amenizada pelo indiscutível tom animado 
e dançante do refrão. No que concerne à letra, o refrão enumera cabelos ilegítimos; seja por sua natureza crespa ("pixaim", "enrolado"), seja por algum penteado transgressor ou mascarador ("colorido") ou por uma ação-atitude de enfrentamento ("assanhado"), propondo uma espécie de conciliação festiva no verso final:

Se eu quero pixaim, deixa

Se eu quero enrolado, deixa

Seu eu quero colorido, deixa

Se eu quero assanhado

Deixa, deixa a madeixa balançar

A tensão deixa/não-deixa opera num terreno conflituoso e ambíguo de afirmação do orgulho negro, podendo ser uma porta de entrada para um debate sobre a canção de Chico César que transcenda a interpretação mecânica da denúncia contra o racismo. Visualmente, a capa do CD opera na mesma ambiguidade, ao expor uma foto do cantor num instigante jogo de luz entre branco e preto que confunde. Nessa composição visual, sua pele parece branca por causa da iluminação e seu cabelo pixaim adquire colocação indefinida sobre o fundo preto. $\mathrm{O}$ terno acinzentado denota certa solenidade respeitosa, reforçada por seu semblante sério.

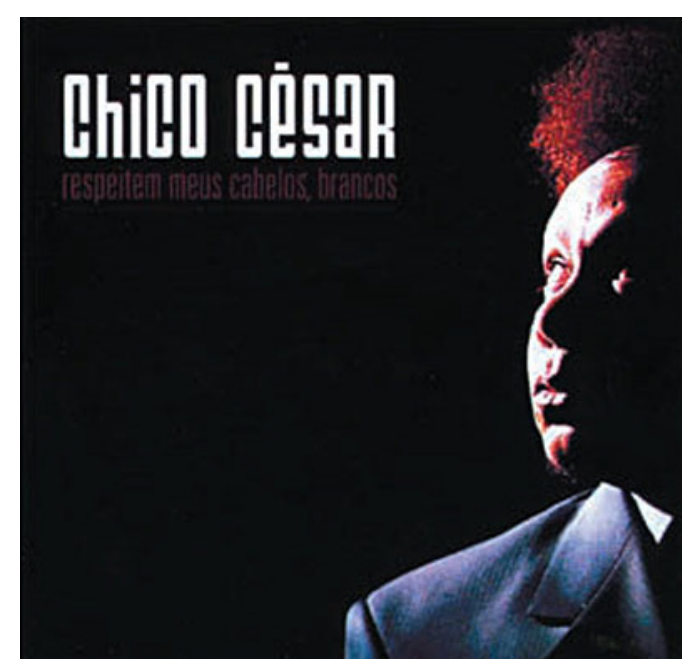


Porém, o olhar para o alto (para o título?) sugere alguma dúvida, ironizando o próprio título do disco e da canção. A tipologia do nome do autor em tamanho bem maior do que o do verso-título também mascara o teor de denúncia, introduzindo certo grau de ambiguidade. Assim, por trás do discurso bipolar, é possível ver e perceber nuances de territórios cinzentos, nebulosos, pouco claros. Se o cabelo é de um negro, mas é de cor branca ou indefinida estamos diante de um discurso anti-preconceito que deve "lidar" com essas indefinições latentes e extremamente desafiadoras. O discurso do orgulho negro e a inconteste exigência de respeito não são construídos num contexto linear e certeiro, mas em um território de dúvidas, ambiguidades e deslocamentos manifestos na capa, na letra, no refrão e na vírgula.

\section{A vírgula: voz, enunciação e ambiguidade}

De acordo com Luiz Tatit, a canção popular tem como núcleo de significação a relação letra-música, que se torna eixo de expressão da voz que fala dentro da voz que canta. "A voz que fala interessa-se pelo que é dito. A voz que canta, pela maneira de dizer. Ambas estão adequadas as suas respectivas funções" (Tatit, 1996, p. 15). Assim, os movimentos melódicos, os prolongamentos e direções do canto buscam intensificar as entoações naturais da fala, adicionando profundidade afetiva no percurso, fixando as ênfases e dinâmicas e estabelecendo, através da relação melódica, um âmbito enunciativo em torno do qual a canção se expressa. No verso inicial da canção, a inflexão musical de maior densidade expressiva é uma pausa entre as palavras "cabelos" e "brancos", a tradução musical da vírgula.

Não é muito arriscado afirmar que parte substancial da densidade expressiva de Respeitem meus cabelos, brancos está materializada na vírgula. É a vírgula que estabelece um fato novo da canção em relação à canção de Herivelto e Marino Pinto. A vírgula transforma o que seria uma função adjetiva do vocábulo "brancos" em um vocativo. 
Com isso, Chico César torce o núcleo semântico verbal da frase que adquire um ar de denúncia que, ao menos à primeira vista, opera num modo de identificação classificatória binário.

Trabalhei com esse negócio da língua quando era jornalista, gosto de escrever, gosto de mexer com as palavras, pensei: 'puxa, uma vírgula aí já muda tudo'. E obviamente essa canção não tem apenas a ver com as coisas que vivi e vivo, mas tem a ver com o cotidiano de milhares de brasileiros afrodescendentes que não podem expressar o que passa dentro da sua cabeça. [...] O pessoal da Casa Grande acha que o da senzala não pode se vestir do jeito que quiser, não pode expressar o que passa dentro do seu coração, dentro da sua cabeça, dentro do seu espírito, dentro da sua alma. É essa coisa de como você se coloca no visual.

(TV Justiça, 2009) $)^{5}$.

A vírgula transforma o cabelo em metonímia de negritude, o que se amplifica quando observamos o artista em sua trajetória midiática. Chico César sempre manipulou seus cabelos e roupas associados à explicitação de sua negritude e, com exceção da capa deste CD especificamente, seus discos buscam uma comunicação visual repleta de significantes "negros".

É claro que tal imagem pública não deixa de ser também uma estratégia de usar a diferença como marketing pessoal, explorando a tensão da diferença e, por vezes, do exótico. Por outro lado, os penteados e roupas do artista vinculam-se à noção de uma inversão estética negra, que nega o referencial capilar branco-europeu-liso hegemônico. 

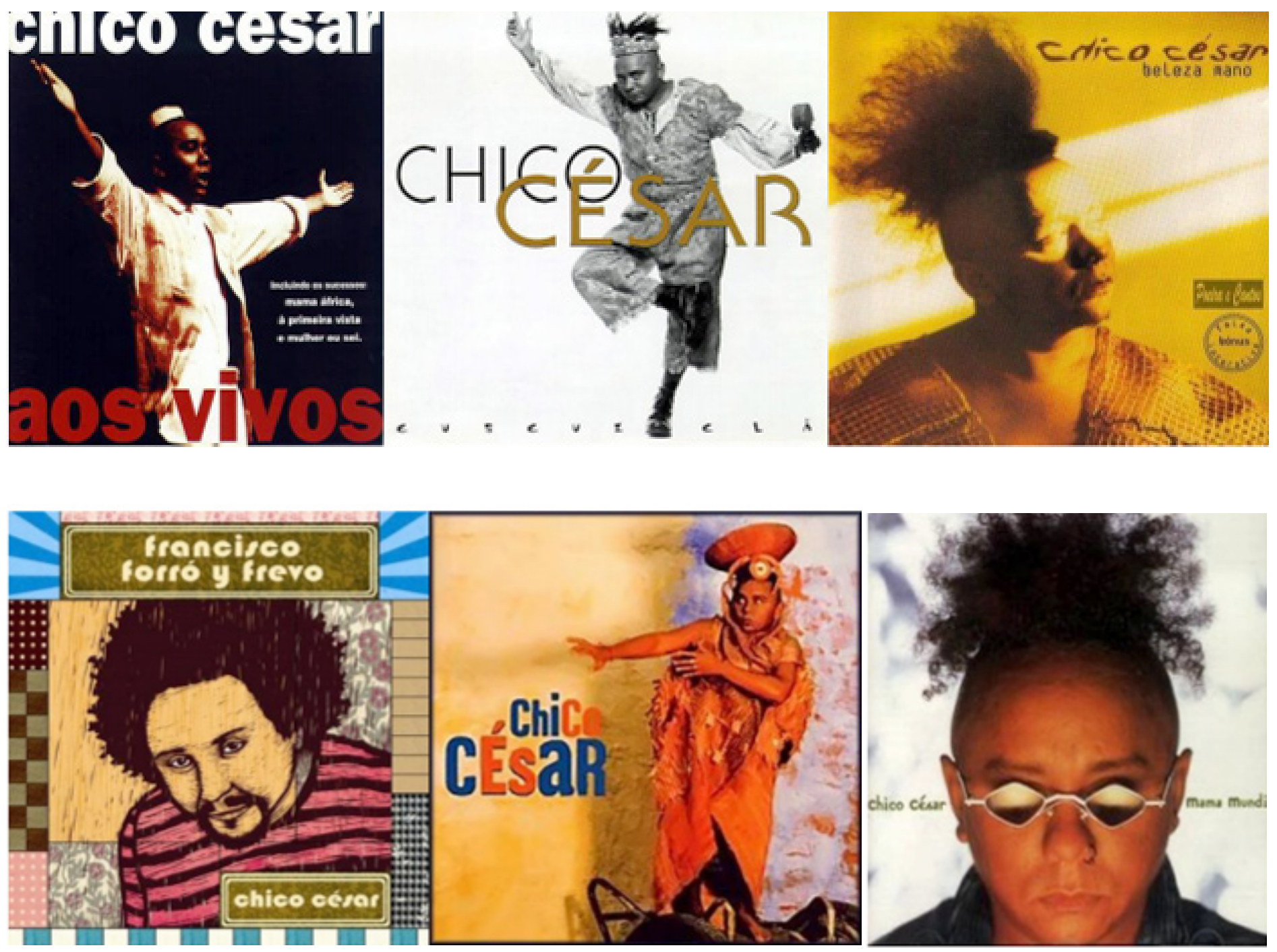
Afinal, "cabelo duro é preciso". Essa postura política dual de construção e negociação da identidade negra se consolida na sequência dos versos, quando o autor desenvolve a ideia de que "chegou a hora de falar".

Respeitem meus cabelos, brancos

Chegou a hora de falar, vamos ser francos

Pois quando um preto fala

O branco cala ou deixa a sala

com veludos nos tamancos

Cabelo vem da África, junto com meus santos

Está posto um discurso de enfrentamento, condizente com o momento histórico do debate sobre as políticas afirmativas e da luta contra o racismo. A oposição binária entre brancos e negros se reforça na enumeração de estereótipos relacionados à aparência e à cultura "negra", num esforço discursivo de inverter a desvalorização e exaltar os elementos classificatórios negros como positivos:

Benguelas, zulus, geges, rebolos, bundos, bantos

Batuques toque, mandingas, danças, tranças, cantos

Respeitem meus cabelos brancos

Respeitem meus cabelos brancos

Contudo, o verso que conclui a estrofe inicial amplia o enfoque discursivo ao repetir o verso-título sem a vírgula. Ao ligar as notas de toda a frase, o vocábulo "brancos" se torna novamente um adjetivo e adiciona o sentido geracional no manifesto. Para não deixar dúvidas, o verso final é repetido. Tanto é importante respeitar os cabelos 
negros do autor quanto os cabelos brancos de sua idade. A frase sem vocativo deixa o interlocutor em aberto e acrescenta a toda a canção certa ironia. A ironia se manifesta quando aparece o "senso de dúvida", revelando uma incongruência, conflito ou contradição que não se apresentava no início (Titler, 1985, p. 33). A que se refere, afinal, o vocábulo "brancos"? Serão ainda os "brancos" do verso inicial, ou eles já deixaram a sala com veludos nos tamancos? E quem seriam esses "brancos"? O cabelo é "branco"?

"A branquitude é um atributo de quem ocupa um lugar social no alto da pirâmide, é uma prática social e o exercício de uma função que força e reproduz instituições, é um lugar de fala para o qual uma certa aparência é condição suficiente.

(Sovik, 2009, p. 50)

Parece-nos clara a ideia de que a canção manifesta-se precisamente contra essa "posição". São esses os brancos do verso-título e o discurso dirige-se contra uma posição social. Não são exatamente pessoas concretas, mas papéis condensados em atitudes racistas e faltas de respeito.

Por outro lado, queremos apontar exatamente que a chave que abre esse discurso também abre outros caminhos a partir do instante em que a palavra "brancos" recupera sua função adjetiva e faz ecoar o samba-canção de Herivelto e Marino. O resultado é uma denúncia irônica, que apresenta um tom sério e zomba deste mesmo tom, ambiguamente. O próprio Chico, ao se defender da seriedade do verso inicial, resume o jogo irônico de sua postura: 
Eu recebi vários e-mails dizendo 'eu era fã do artista Chico César, mas essa música raivosa, trazendo uma discussão que não faz sentido, nós somos um país de democracia racial, e agora não sou mais fã porque ele é um artista raivoso' e tal. Não se trata de ser raivoso ou de ser amoroso, se trata de ser realista, e dentro de uma perspectiva realista trazer questões pro ambiente da representação subjetiva que fazem parte das coisas que a gente vive. É como você proibir Portinari de pintar um camponês, ou um pintor de Pernambuco de pintar um cortador de canade-açúcar naquelas condições. Existem as condições.

(Tv Justiça, 2009) $)^{6}$

A resposta já está dada pela canção. A denúncia é feita, mas através dela mesma busca-se agregar complexidades. Nesse sentido, é fundamental a presença do cantor/ compositor como veículo da mensagem. A voz corporifica o conteúdo da fala/canto, apresentando um sujeito narrador, que compartilha com certa coletividade seus dilemas afetivos, morais, estéticos ou de qualquer outra natureza. A imagem pública de Chico César, a capa do CD e o reconhecimento do reggae podem ser pensados como elementos que moldam a posição de fala/canto do "eu" da canção. O traço irônico se faz presente em sua trajetória na forma de abordar seus referenciais identitários pessoais e coletivos (negritude e nordestinidade). O deslocamento da vírgula é, portanto, análogo à Mama África empacotadeira ou ao não-uso do reggae em Pedra de responsa. Todos falam de ambientes de preconceito e estereótipos, mas fogem tangencialmente de afirmações categóricas em leves torções de sentido.

Somam-se a eles o plano de entoação (que envolve a composição e a interpretação) da gravação, formado pelo âmbito médio-agudo de sua tessitura vocal (sobre- 
tudo nos versos iniciais da canção) e pelas ocorrências do coro (a própria coletividade) no refrão e na repetição da letra. Sob ponto de escuta da estruturação melódica e harmônica, há outro elemento significativo para a ambientação de um clima bem menos binário do que o título sugere. A canção encontra-se na tonalidade de sol menor $(\mathrm{Gm})$, oscilando em suas estrofes iniciais para seu relativo maior, sib bemol (Bb). Essa mudança provisória do centro tonal (espaço harmônico de repouso da música) pode ser interpretada como uma intencional manifestação de uma fuga de sentidos entre a vírgula e a não-vírgula. $\mathrm{O}$ modo menor seria um modo mais propício à enunciação de estados disfóricos, a perdas ou desilusões (Tatit, 1996). Por outro lado, o modo maior seria dotado de maior força agressiva, mais aberto e consonante. A transição entre os dois modos resulta numa diluição dessas representações asseguradas e busca operar no limite. É como se a tônica fugisse entre sol e si bemol deixando a sensação de repouso oscilar continuamente.

O que queremos apontar aqui é que a ambiguidade tonal reforça a dupla interpretação do verso-título, estruturando uma rede de significados que resvala para todo o $\mathrm{CD}$ e, mais além, para sua obra e para um posicionamento político no cenário das disputas raciais no Brasil. Em outras palavras, temos que enfrentar de alguma forma a vírgula que desloca, que amplia e que perturba nosso ambiente cultural ainda cercado de muito preconceito e de muita falta de respeito.

\section{Conclusão: música e ação política}

A experiência musical é uma manifestação coletiva de compartilhamento de ideias, valores, crenças e modos de pertencimento, o que envolve disputas, conflitos e negociações sociais. Nesse sentido, gêneros musicais como o jazz, o reggae e o samba, nascidos em contextos formados majoritariamente por negros, colocam em cena, 
de modo amplificado, as tensões relacionadas ao racismo. Ao mesmo tempo, as canções inscritas nesses gêneros negociam seu pertencimento num contexto midiático de produção e circulação, dialogando com toda a sociedade. Seja pela adesão de músicos brancos ao ambiente norte-americano do jazz (Hobsbawn, 2009, p. 213), pela amplitude globalizante anglófana propagada pelo reggae (Gilroy, 2001, p. 194-197) ou pela síntese rítmica e cultural processada pelo samba (Sandroni, 2001, p. 222), o significante "negro" está pressionado pela hegemonia de uma estética e de uma economia de poder construída para sedimentar a superioridade dos "brancos". Entre o mito da democracia racial e a opção da denúncia acusatória, a música popular apresenta rotas de fuga, ironias e modos de discutir profundamente o racismo sem resvalar em essencialismos biológicos ou negar o fato de que as dissimulações revelam uma noção compartilhada de que "a aparência das pessoas não deveria influir sobre suas escolhas e carreiras" (Fry, 1996, p. 132), mesmo que se reconheça que influi. O terreno é cheio de pedras e curvas, e com frequência há algo mais a ser dito ou pensado.

Uma interpretação literal da dimensão verbal da canção e do CD tenderia a reificar uma posição dogmática, temperada de agressividade e ressentimentos. Optamos, ao contrário, por desvelar ambiguidades e elementos da construção sonoro-imagéticodiscursiva que aprofundam o escopo argumentativo do debate e agregam densidade à temática. A instabilidade tonal, o deslocamento da vírgula, o jogo de luz e sombra da foto da capa e a apropriação não-ortodoxa do reggae acionam posições discursivas que ampliam as possibilidades de reflexão sobre a questão étnica no Brasil. E, ao final da canção, ainda brincando ironicamente com a contundência de seu discurso, Chico César indaga, após o último acorde da gravação, uma pergunta quase inaudível que "encerra" a questão ao mesmo tempo que abre dúvidas, desloca certezas e assenta-se em contradições: "Fui claro?" 


\section{REFERÊNCIAS}

BLACKING, John. Music, culture and experience. Chicago, EUA: Chicago University Press, 1995.

CARVALHO, José Jorge de. Black music of all colors. Série Antropologia n. 145. Departamento de Antropologia da UnB. Brasília: Unb, 1993. Disponível em: <http://vsites.unb.br/ics/dan/serie_antro.htm>. Acesso em: 15 jun. 2009.

COUTINHO, Eduardo. Velhas histórias, memórias futuras. Rio de Janeiro: EdUERJ, 2001.

FABBRI, Franco. A theory of musical genres: two applications. In: HORN, David; TAGG, Philip (eds.). Popular music perspectives. IASPM, Göteborg \& Exeter, 1982.

FRY, Peter. O que a Cinderela Negra tem a dizer sobre a "política racial" no Brasil. Revista da USP, n. 28. São Paulo: EdUSP, 1996. p. 122-135.

GILROY, Paul. O Atlântico negro: modernidade e dupla consciência. São Paulo: Ed. 34, 2001.

GOMES, Nilma Lino. Sem perder a raiz. Belo Horizonte: Autêntica, 2006.

HALL, Stuart. Da diáspora: identidades e mediações culturais. Belo Horizonte: Editora da UFMG, 2003. p. 317-330.

HEBDIGE, Dick. Subculture: the meaning of style. Reino Unido: Routledge, 2009.

HOBSBAWM, Eric. História social do jazz. Rio de Janeiro: Paz e Terra, 1990.

JANOTTI JUNIOR, Jeder. Música popular massiva e gêneros musicais. In: Anais XV Compós, Bauru, UNESP, 2006.

KELLNER, Douglas. A cultura da mídia. Bauru, SP: EDUSC, 2001.

MERCER, Kobena. Black hair/style politics. New Formations, Londres: Lawrence \& Wishart, n. 3. p. 33-54, 1987.

ORTIZ, Renato. A diversidade dos sotaques. São Paulo: Brasiliense, 2008.

ROMMEN, Timothy. Protestant vibrations? Reggae, Rastafari and conscious Evangelicals. Popular music, Cambridge: Cambridge University Press, v. 25, n. 2, p. 235-263, 2006.

SANDRONI, Carlos. O feitiço decente. Rio de Janeiro: EdUFRJ/Zahar, 2001.

SANSONE, Livio. Negritude sem etnicidade. Salvador: EDUFBA, 2007.

SCHWARCZ, Lília M. Raça sempre deu o que falar [Prefácio]. In: FERNANDES, Florestan O negro no mundo dos brancos. São Paulo: Global, 2007.

SODRÉ, Muniz. Samba, o dono do corpo. Rio de Janeiro: Mauad, 1998. 
SOVIK. Liv. Aqui ninguém é branco. Rio de Janeiro: Aeroplano, 2009.

TATE, Shirley. Black beauty. Inglaterra/EUA: Ashgate Publishing, 2009.

TITLER, Johathan. Approximately irony. Modern Language Studies, Reino Unido: Oxford University Press, v. 15, n. 2, p. 32-46, 1985.

\section{NOTAS}

1 A música pode ser ouvida no link: <http://www.4shared.com/audio/RhgGEuXe/Respeitem_Meus_Cabelos_ Brancos.htm>.

2 Publicado em 28 jun. 2008 sob o título "Vídeo infeliz" no site "Obra em Aberto", de Caetano Veloso: <http:// www.obraemprogresso.com.br/2008/06/28/carlos-sandroni-responde-a-caetano-sobre-o-feitico-de-noel/>. Acesso em: 12 dez. 2010.

3 Termo bastante recorrente entre os "regueiros" usado para denotar os clássicos do reggae como as músicas de Bob Marley e Jimmy Cliff, também usado como adjetivo na definição de um reggae considerado como muito bom.

4 Fricote, de Luiz Caldas, 1986.

5 Entrevista ao programa Refrão da TV Justiça em 03 de abril de 2009. Disponível em: <http://www.direito2. com.br/stf/2009/abr/3/programa-refrao-da-tv-justica-estreia-comchico-cesar-e-a-musica>. Acesso em: 02 jan. 2010.

6 Entrevista ao programa Refrão da TV Justiça em 03 de abril de 2009. Disponível em: <http://www.direito2. com.br/stf/2009/abr/3/programa-refrao-da-tv-justica-estreia-comchico-cesar-e-a-musica>. Acesso em: 02 jan. 2010. 